ARTIKEL

\title{
KEBIJAKAN BANDUNG TRANSIT AREA (BTA) UNTUK PENINGKATAN KUNJUNGAN WISATA
}

\author{
Deding Ishak, Endah Ratnawaty Chotim, \\ Dedeng Yusuf Maolani, Avid Leonardo Sari
}

STAI Yapata Al-Jawami Bandung, Jurusan Sosiologi \& Jurusan Administrasi Publik Universitas Islam Negeri (UIN) Sunan Gunung Djati (SGD) Bandung

E-mail: deding1962@gmail.com

\begin{abstract}
The main problem in this research is the role and function of tourism component and government is still low. This is caused by tourism activities have not been fully managed properly. The purpose of this research is: (1) Formulating the optimization str ategy of tourism destination component of Bandung Transit Area (BTA). (2) to formulate strategies to optimize the government's role in the development of Bandung Transit Area (BTA). The research method used is SWOT analysis which stands for Strength (S), Weakness (W), Opportunities (O), and Threats (T) which means strengths, weaknesses, opportunities and threats / constraints, which can systematically help identify factors factors: outside $(O$ and $T)$ and factors in the organization ( $S$ and $W)$. The initial phase of the research is to assess the strengths, weaknesses, opportunities, and threats that the organization has. The results of the analysis can be changes in mission, goals, policies, or strategies that are running. The result of research that Role of Tourism in Bandung area have become an industry and have a big role in Bandung area development. Bandung area is a major tourist destination in West Java. In addition, various factors such as the position of Bandung as the center of government, service centers, and economic activities, and geographical conditions of Bandung area became one of the main tourist destinations in West Java.
\end{abstract}

Keyword: Tourism Components, Government Roles, Policy Strategies

\begin{abstract}
Abstrak
Masalah utama dalam penelitian ini adalah peran dan fungsi komponen pariwisata dan pemerintah masih rendah. Hal ini disebabkan oleh kegiatan bidang pariwisata belum sepenuhnya dikelola dengan baik.Tujuan penelitian ini adalah: (1) menyusun strategi optimalisasi komponen destinasi wisata Bandung Transit Area (BTA). (2) menyusun strategi optimalisasi peranan pemerintah dalam pembangunan Bandung Transit Area (BTA). Metode penelitian yang digunakan adalah analisis SWOT yang merupakan singkatan dari Strength (S), Weakness (W), Opportunities (O), dan Threats ( $\mathrm{T}$ ) artinya kekuatan, kelemahan, peluang dan ancaman/kendala, dimana secara sistematis dapat membantu dalam mengidentifikasi faktor-faktor: luar ( $\mathrm{O}$ dan T) dan faktor di dalam organisasi (S dan W). Tahap awal penelitian adalah menaksir kekuatan, kelemahan, kesempatan, dan ancaman yang dimiliki organisasi. Hasil analisis dapat dilakukan perubahan pada misi, tujuan, kebijakan, atau strategi yang sedang berjalan. Hasil penelitian bahwa Peran Pariwisata di wilayah Bandung telah menjadi suatu industri dan memiliki peran yang besar bagi pembangunan Wilayah Bandung.
\end{abstract}


Wilayah Bandung merupakan kota tujuan wisata utama di wilayah Jawa Barat. Selain itu berbagai faktor seperti posisi Bandung sebagai pusat pemerintahan, pusat kegiatan jasa dan kegiatan perekomian, serta kondisi geografis wilayah Bandung mendukung untuk menjadi salah satu tujuan wisata utama di Jawa Barat.

Kata Kunci: Komponen-Komponen Pariwisata, Peran Pemerintah, Strategi Kebijakan

\section{A. Pendahuluan}

Pertumbuhan kunjungan wisatawan ke Kabupaten Bandung tahun 2009-2013 (Dinas Pariwisata Kabupaten Bandung) memiliki potensi cukup tinggi. Hal ini karena banyaknya keanekaragaman wisata di Kabupaten Bandung. Berdasarkan tabel mengenai pertumbuhan kunjungan wisata ke Kabupaten Bandung diketahui dari jumlah kunjungan wisata ke Kabupaten Bandung mengalami kenaikan selama kurun waktu tahun 2009-2013. Pada tahun 2009 tercatat 35.834.475 orang. Pada tahun 2010 mengalami penurunan karena masalah kemacetan dan kerusakan infrastruktur menjadi 34.647.240 orang. Pada tahun 2011 sejumlah 36.712.729 orang. Pada tahun 2012 sejumlah 39.467.642 orang dan pada tahun 2013 menjadi 44.663 .441 orang. Jumlah kunjungan wisata ke Kabupaten Bandung diperkirakan akan terus meningkat karena Kabupaten Bandung memiliki beragam Daya Tarik Wisata (DTW).

Jumlah obyek wisata yang ada di Kabupaten Bandung sejak tahun 2010 sebanyak 53 obyek. Jumlah kunjungan yang sebanyak 4.607.330 orang pada tahun 2010 . Jumlah ini meningkat bila dibandingkan dengan tahun-tahun sebelumnya (tahun 20082009), dimana pada tahun 2008 sebanyak 4.306 .602 orang dan pada tahun 2009 sebanyak 4.126.434 orang yang berkunjung ke 53 obyek. Dari data tersebut dapat diketahui rata-rata jumlah pengunjung pada masing-masing obyek wisata sebanyak 50.273 pada tahun 2008, sebanyak 77.857 orang pada tahun 2009 dan sebanyak 86.930 orang pada tahun 2010. 
ARTIKEL

\section{Jumlah Kunjungan Wisata di Kabupaten Bandung Pada Tahun 2008 - 2010}

\begin{tabular}{|c|l|r|r|r|}
\hline No. & \multicolumn{1}{|c|}{ Uraian } & \multicolumn{1}{|c|}{$\mathbf{2 0 0 8}$} & $\mathbf{2 0 0 9}$ & $\mathbf{2 0 1 0}$ \\
\hline 1. & $\begin{array}{l}\text { Jumlah obyek wisata } \\
\text { (obyek) }\end{array}$ & 49 & 49 & 53 \\
\hline 2. & $\begin{array}{l}\text { Jumlah kunjungan } \\
\text { wisata (orang) }\end{array}$ & 4.306 .602 & 5.458 .218 & 6.069 .539 \\
\hline 3. & $\begin{array}{l}\text { Rata-rata kunjungan per } \\
\text { obyek wisata (orang) }\end{array}$ & 87.890 & 111.392 & 123.869 \\
\hline
\end{tabular}

Jalan tol merupakan jalan alternatif untuk mempercepat sarana transportasi, perkembangan industri pariwisata, menunjang pertumbuhan dan percepatan perekonomian yang kerap terhambat karena kendala transportasi, mengurangi kemacetan akibat pasar tumpah, pasar tradisional, penyempitan jalan, jembatan rusak, jalan yang berlubang dan lain-lain adalah hal yang menghambat proses ekonomi secara merata dan cepat.

Pembangunan jalan tol Soreang - Pasir Koja (SOROJA) merupakan salah satu solusi bagi permasalahan akses dari dan menuju Kota Soreang. Pembangunan tersebut juga akan membuka akses Kabupaten Bandung bagian selatan dari dan menuju Kabupaten Bandung maupun kota-kota lainnya yang terhubung dengan jaringan Jalan Tol Padaleunyi. Pembangunan jalan tol tersebut dapat meningkatkan arus pergerakan modal, barang, dan orang. Kesejahteraan masyarakat dapat meningkat jika mendapatkan manfaat dari kelancaran pergerakan. Keberadaan jalan tol SOROJA diperkirakan akan menyebabkan meningkatnya volume lalu lintas pada 6 koridor tersebut, sehingga tingkat pelayanan jalan juga ikut menurun. Dari hasil penelitian diketahui bahwa dengan adanya pembangunan jalan tol SOROJA menyebabkan kenaikan volume per kapasitas,yaitu : Koridor Pasir Koja-Bandung

Sebagai sebuah kawasan wisata yang memiliki 2 (dua) buah fungsi, yaitu sebagai destinasi (destination) wisata dan fungsi distribusi (chanelling) BTA produk yang akan ditawarkan diantaranya adalah wisata kuliner, wisata belanja, MICE dan wisata yang khas, yaitu wisata religi. Secara khusus wisata religi bertujuan menarik wisatawan dari 
ARTIKEL

Jakarta untuk mendalami pemahaman agama. Keberadaan Bandung Transit Area (BTA) yang berfungsi ganda, yaitu sebagai destinasi wisata dan sebagai chanelling ke destinasi wisata yang ada wilayah Kabupaten Bandung merupakan salah satu instrument yang dibangun sebagai respon terhadap keberadaan jalan Tol SOROJA. Rumusan masalah pada penelitian tersebut yaitu, (1) Bagaimana strategi optimalisasi komponen destinasi wisata pada Bandung Transit Area (BTA)?. (2) Bagaimana strategi optimalisasi peranan pemerintah dalam pembangunan Bandung Transit Area (BTA)? Adapun tujuannya adalah (1) Menyusun Strategi Optimalisasi Komponen Destinasi Wisata Pada Bandung Transit Area (BTA). (2)Menyusun Strategi Optimalisasi Peranan Pemerintah Dalam Pembangunan Bandung Transit Area (BTA).

\section{B. Teori dan Metode Penelitian}

Pariwisata adalah kegiatan rekreasi di luar domisili untuk melepaskan diri dari pekerjaan rutin atau mencari suasana lain. Sebagai suatu aktifitas, pariwisata telah menjadi bagian penting dari kebutuhan dasar masyarakat maju dan sebagian kecil masyarakat negara berkembang. Hidup seolah-olah didesain untuk produksi dan pekerjaan, sehingga tidak jarang mengakibatkan orang stress. Pariwisata kemudian menjadi kanal yang tepat untuk membebaskan masyarakat dari tekanan tersebut (Janianton, 2006 : 1). Berdasarkan dua pokok pikiran tersebut, skala prioritas pembangunan dan pengembangan daerah tujuan wisata, diputuskan untuk dibangun sebagai 10 daerah tujuan wisata di sepuluh provinsi, yaitu: Konsepsi Pariwisata, tersedianya prasarana, sarana dan fasilitas-fasilitas lainnya serta besarnya potensi kepariwisataan di daerah yang bersangkutan.

Pariwisata memiliki faktor daya tarik, yaitu: (1) alam, keindahan alam (topografi umum seperti flora dan fauna di sekitar danau, sungai, pantai, laut, pulaupulau, mata air panas, sumber mineral, teluk, gua, air terjun, cagar alam, hutan, dsb.). (2) iklim (sinar matahari, suhu udara, cuaca, angin, hujan, panas, kelembaban, dsb.). (3) sosial Budaya, adat-istiadat (pakaian, makanan dan tata cara hidup daerah, pesta rakyat, kerajinan tangan dan produk-produk lokal lainnya.). (4) seni, bangunan (arsitektur setempat seperti candi, pura, mesjid, gereja, monument bangunan adat, dsb.). (5) pentas \& pagelaran, festival (gamelan, musik, seni tari dan pekan olah 
ARTIKEL

raga kompetisi \& pertandingan, dsb.). (6) pameran pekan raya (pekan-pekan raya yang bersifat industri komersial). (7) sejarah - Peninggalan purbakala (bekas-bekas istana, tempat peribadahan, kota tua dan bangunan-bangunan purbakala peninggalan sejarah, dongeng atau legenda.). (8) agama - Kegiatan masyarakat (kehidupan beragama tercermin dari kegiatan penduduk setempat sehari-harinya dalam soal beribadah, upacara, pesta, dsb.). (9) fasilitas rekreasi. (10) olahraga (berburu, memancing, berenang, main ski, berlayar, golf, naik kuda, mendaki, dsb.). (11) edukasi (museum arkeologi dan etnologi, kebun binatang, kebun raya, akuarium, planetarium, laboratorium, dsb.). Fasilitas kesehatan - untuk istirahat, berobat dan ketenangan (SPA mengandung mineral, SPA air panas, sanatorium, tempat mendaki, piknik, tempat semedi, istirahat, dsb.). (12) fasilitas berbelanja beli ini-itu (toko-toko souvenir, toko-toko barang kesenian dan hadiah, toko-toko keperluan sehari-hari, kelontong, dsb.). (13) fasilitas hiburan - waktu malam (kasino, night club, disko, bioskop, teater, sandiwara, dsb.). (14) infrastruktur kualitas wisata (jalan-jalan raya, taman, listrik, air, pelayanan keamanan, pelayanan kesehatan, komunikasi, kendaraan umum, dsb.). (15) fasilitas pangan dan akomodasi - makanan \& penginapan (hotel, motel, bungalow, inn, cottage, guest house, restoran, coffeeshop, rumah makan, dsb.)

Prasarana umum (general infrastructure): Kebutuhan masyarakat banyak (Basic Needs of Civilized Life), yaitu prasarana yang menyangkut kebutuhan masyarakat banyak. Dan yang termasuk dalam kelompok ini adalah: (1) rumah sakit, klinik, puskesmas. (2) apotek. (3) bank. (4) kantor Pos. (5) SPBU (Stasiun Pengisian Bahan bakar Umum). (6) administration offices (pemerintahan umum, polisi, pengadilan, badan-badan legislatif, dsb.)

Secara terperinci, dapat kita gambarkan jasa-jasa yang merupakan produk industri pariwisata yang dibutuhkan seorang wisatawan, semenjak ia meninggalkan tempat kediamannya hingga ia kembali ke rumahnya, secara berurutan adalah sebagai berikut: Hasil (Produk) Industri Pariwisata, (a) Tourists objects: (b) Facilities: (c) Transportation: Transportasi yang menghubungkan negara asal wisatawan dengan daerah tujuan wisata serta transportasi di tempat tujuan ke objekobjek pariwisata. 
ARTIKEL

Manfaat Pariwisata: (1) peningkatan pertumbuhan urbanisasi sebagai akibat adanya pembangunan prasarana dan sarana kepariwisataan dalam suatu wilayah atau suatu daerah tujuan. (2) pertumbuhan kegiatan beberapa industri, yang berhubungan dengan pelayanan wisatawan, seperti perusahaan angkutan, akomodasi perhotelan, restoran, entertainments, souvenir shop, handicraft, kesenian daerah, perusahaan mebel, decoration and gardening, pendidikan, dan lain-lain. (3) meningkatkan produk hasil kepariwisataan disebabkan meningkatnya konsumsi wisatawan, seperti timbulnya istilah kebudayaan komersil demi kebutuhan wisatawan.(4) Menyebarkan pemerataan pendapatan. (5) membantu dalam pemerataan pendapatan penduduk dunia. (6) salah satu jalan atau usaha pemerintah dalam rangka meningkatkan devisa negara. (7) menimbulkan multiplier effect (efek pengganda) pada negara-negara "tourist receiving countries".

Persepsi dan Partisipasi Masyarakat Lokal atas Kepariwisataan: Persepsi adalah proses dimana kita mengorganisasi dan menafsirkan pola stimulus di dalam lingkungan (Atkinson dalam Ginting, 2006). Chaplin dalam Ginting (2006) memandang persepsi sebagai proses mengetahui atau mengenali objek dan kejadian objektif dengan bantuan indra. Proses perseptual ini dimulai dengan perhatian, yaitu merupakan proses pengamatan selektif. Di dalamnya mencakup pemahaman dan mengenali atau mengetahui objek-objek serta kejadian-kejadian (Chaplin dalam Ginting, 2006).

Menurut Wheelen dan Hunger (2012: 16), pengertian / definisi analisis SWOT (Strength, Weakness, Opportunities, dan Threats). Analisa SWOT adalah suatu metoda penyusunan strategi perusahaan atau organisasi yang bersifat satu unit bisnis tunggal. Ruang lingkup bisnis tunggal tersebut dapat berupa domestik maupun multinasional. SWOT itu sendiri merupakan singkatan dari Strength (S), Weakness (W), Opportunities $(\mathrm{O})$, dan Threats $(\mathrm{T})$ yang artinya kekuatan, kelemahan, peluang dan ancaman atau kendala, dimana yang secara sistematis dapat membantu dalam mengidentifikasi faktorfaktor luar (O dan T) dan faktor didalam perusahaan (S dan W). Kata-kata tersebut dipakai dalam usaha penyusunan suatu rencana matang untuk mencapai tujuan baik untuk jangka pendek maupun jangka panjang.

Petunjuk umum yang sering diberikan untuk perumusan adalah : (1) memanfaatkan kesempatan dan kekuatan (O dan S). Analisis ini diharapkan 
membuahkan rencana jangka panjang.(2) Atasi atau kurangi ancaman dan kelemahan ( $\mathrm{T}$ dan $\mathrm{W}$ ). Analisa ini lebih condong menghasilkan rencana jangka pendek, yaitu rencana perbaikan (short-term improvement plan).

Tahap awal proses penetapan strategi adalah menaksir kekuatan, kelemahan, kesempatan, dan ancaman yang dimiliki organisasi. Analisis SWOT memungkinkan organisasi memformulasikan dan mengimplementasikan strategi utama sebagai tahap lanjut pelaksanaan dan tujuan organiasasi, dalam analisa SWOT informasi dikumpulkan dan dianalisa. Hasil analisa dapat menyebabkan dilakukan perubahan pada misi, tujuan, kebijaksanaan, atau strategi yang sedang berjalan.

\section{Hasil dan Pembahasan}

Pariwisata telah menjadi suatu industri dan memiliki peran yang sangat besar bagi pengembangan pembangunan Kabupaten Bandung. Kabupaten Bandung merupakan salah satu kota tujuan wisata utama di wilayah Jawa Barat. Selain itu berbagai faktor seperti posisi Kabupaten Bandung sebagai pusat pemerintahan, pusat perekonomian, pusat perdagangan dan industri atau dapat dikatakan sebagai pusat kegiatan jasa dan kegiatan perekomian Jawa Barat, serta kondisi geografis Kabupaten Bandung mendukung untuk menjadi salah satu tujuan wisata utama di Jawa Barat.

Pemerintah Kabupaten Bandung memberikan perhatian bagi perkembangan kepariwisataan di Kabupaten Bandung dengan tujuan memperoleh dampak positif dari industri pariwisata seperti jalan untuk menuju objek wisata yang tentunya akan berdamoak bagi peningkatan ekonomi masyarakat, dan menjadikan industri pariwisata sumber potensial bagi pemasukan pendapatan daerah.Kegiatan pariwisata di Kabupaten Bandung diharapkan dapat terus berkembang. Salah satu untuk melihat kecenderungan pertambahan wisatawan yang datang ke Kabupaten Bandung pada tabel berikut : 
ARTIKEL

Tabel 3.1

Tabel Kunjungan Wisatawan Tahun 2010-2013

\begin{tabular}{|c|c|c|c|c|c|}
\hline Tahun & $\begin{array}{c}\text { Wisatawan } \\
\text { Mancanegara }\end{array}$ & $\begin{array}{c}\text { Wisatawan } \\
\text { Domestik }\end{array}$ & $\begin{array}{c}\text { Jumlah } \\
\text { Wisatawan }\end{array}$ & $\begin{array}{c}\text { Jumlah } \\
\text { Tamu } \\
\text { Menginap }\end{array}$ & $\begin{array}{c}\text { Tingkat } \\
\text { Okupansi } \\
\text { Hotel }\end{array}$ \\
\hline 2010 & 685.347 & 14.854 .317 & 15.539 .664 & 9.615 .807 & $62 \%$ \\
\hline 2011 & 676.755 & 19.461 .717 & 20.138 .472 & 12.228 .216 & $61 \%$ \\
\hline 2012 & 530.565 & 15.241 .752 & 15.772 .317 & 10.541 .115 & $67 \%$ \\
\hline 2013 & 529.296 & 16.164 .876 & 16.694 .172 & 11.692 .287 & $70 \%$ \\
\hline
\end{tabular}

Sumber: Dinas Kebudayaan dan Pariwisata Kota Bandung (2014)

Destinasi Wisata

Berikut Destinasi wisata berdasarkan Tipologi potensi daya tarik wisata di Kabupaten Bandung :

Tabel 3.2

Tipologi Potensi Daya Tarik Wisata Kabupaten Bandung

\begin{tabular}{|l|l|}
\hline No. & Jenis Daya Tarik \\
\hline 1 & Wisata Heritage (Wisata Peninggalan Sejarah) \\
\hline 2 & Wisata Belanja dan Kuliner \\
\hline 3 & Wisata Pendidikan \\
\hline 4 & Rekreasi dan Hiburan (Alam, Budaya, Buatan) \\
\hline 5 & MICE (Meeting, Incentive, Convention and Exhibition) \\
\hline
\end{tabular}

Sumber: RIPPDA Kabupaten Bandung, 2006

Karakteristik Wisatawan

Menurut data Laporan Bappeda Kabupaten Bandung tahun 2015, bahwa karakteristik wisatawan di Kabupaten Bandung terbagi tiga, yaitu : Domestik/Nusantara dan Internasional, sementara yang ketiga adalah para day tripper, yaitu para pengunjung datang dan melakukan aktivitas di Kabupaten Bandung dalam waktu kurang 24 jam. Pengunjung yang datang ke Kabupaten Bandung untuk berbagai keperluan.

Pola Pergerakan Wisatawan

Wisatawan yang datang ke Kabupaten Bandung terbagi ke dalam dua kelompok besar, yaitu wisatawan domestik dan wisatawan mancanegara (wisman). Untuk wisatawan nusantara, wisatawan yang datang ke Kabupaten Bandung masih didominasi oleh wisatawan dari wilayah sekitar Jabodetabek apalagi setelah dibukanya 


\section{ARTIKEL}

akses melalui jalan Tol Purbaleunyi yang memudahkan akses menuju Kabupaten Bandung dan wisatawan lainnya yang berasal dari kabupaten / kota lain di Jawa Barat.

Gambar 3 : Pola Perjalanan Wisatawan Mancanegara Ke Kabupaten Bandung

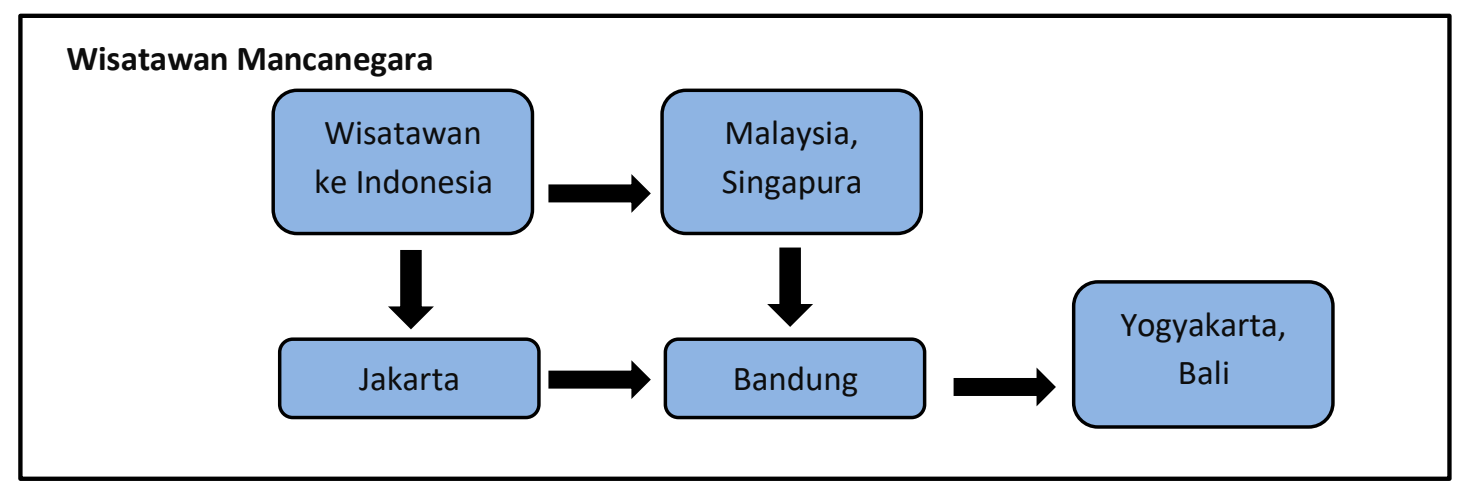

Sumber: RIPPDA Kabupaten Bandung, 2006

\section{Gambar 4 : Pola Perjalanan Wisatawan Nusantara Ke Kabupaten Bandung}

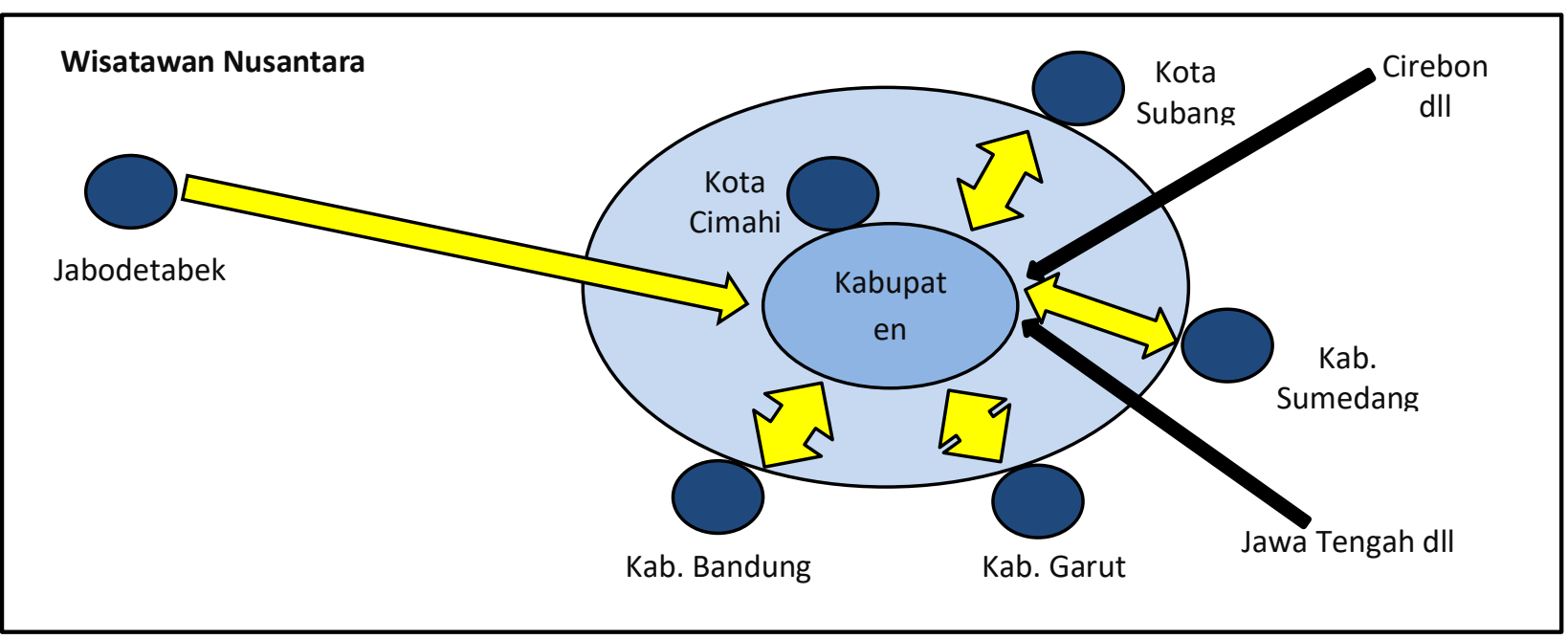

Sumber: RIPPDA Kabupaten Bandung Tabun 2006 
Berikut dapat dilihat segmentasi pasar wisatawan yang datang ke Kabupaten Bandung pada tabel-tabel berikut :

Tabel 3.3

\section{Segmentasi Pasar Wisatawan Nusantara Di Kabupaten Bandung}

\begin{tabular}{|c|c|}
\hline Aspek & si \\
\hline $\begin{array}{l}\text { Aspek Geografis } \\
\text { (Geographic } \\
\text { Segmenting) }\end{array}$ & $\begin{array}{l}\text { Wisatawan asal daerah sekitar Kabupaten Bandung (Kab. } \\
\text { Bandung, Sumedang, Subang, Garut, Purwakarta, Cianjur, } \\
\text { dan Kota Cimahi. } \\
\text { Wisatawan asal Jabodetabek (Jakarta, Bogor, Depok, } \\
\text { Tanggerang dan Bekasi). } \\
\text { Wisatawan asal Kabupaten/Kota lainnya di Jawa Barat, } \\
\text { Banten, Jawa Tengah dan Yogyakarta. }\end{array}$ \\
\hline $\begin{array}{l}\text { Aspek Demografis } \\
\text { (Demographic } \\
\text { Segmenting) }\end{array}$ & $\begin{array}{l}\text { Wisatawan remaja. } \\
\text { Wisatawan keluarga. } \\
\text { Cenderung memiliki edukasi yang baik. } \\
\text { Memiliki daya beli yang bervariasi, mulai dari yang } \\
\text { membatasi diri dalam berbelanja maupun yang memiliki } \\
\text { kebebasan dalam berbelanja. }\end{array}$ \\
\hline $\begin{array}{l}\text { Aspek Psikologis } \\
\text { (Psychographic } \\
\text { Segmenting) }\end{array}$ & $\begin{array}{l}\text { Mayoritas bertujuan untuk melakukan rekreasi, sebagian } \\
\text { besar melakukan bisnis dan MICE. } \\
\text { Telah menjadikan Kabupaten Bandung sebagai daerah } \\
\text { tujuan utama wisata mereka. } \\
\text { Kabupaten Bandung telah ditetapkan sebagai wisata } \\
\text { perkotaan (belanja dan Kuliner) dan wisata alam } \\
\text { pegunungan. } \\
\text { Sebagian besar wisatawan yang datang menggunakan } \\
\text { kendaraan pribadi, namun cukup signifikan yang } \\
\text { menggunakan kendaraan umum. } \\
\text { Lama tinggal kurang dari } 1 \text { hari, dan 1-2 hari. } \\
\text { Untuk wisatawan yang menginap, cenderung menggunakan } \\
\text { hotel baik itu hotel melati maupun hotel berbintang. }\end{array}$ \\
\hline
\end{tabular}




\begin{tabular}{|l|l|}
\hline Perilaku Berwisata & Sifat kunjungan cenderung individual dan berkelompok. \\
(Behaviouristic & Pengunjung repeater jumlahnya cukup banyak. \\
Segmenting) & Adanya keinginan dari wisatawan untuk mendapatkan \\
pilihan wisata yang memberikan pengetahuan dan \\
pengalaman yang dikemas secara menarik. \\
Menikmati keanekaragaman pilihan cideramata asal \\
Kabupaten Bandung baik berupa barang maupun berupa \\
makanan. \\
Kurangnya apresiasi terhadap atraksi budaya sunda karena \\
keterbatasan akan atraksi budaya yang ditawarkan.
\end{tabular}

Sumber: RIPPDA Kabupaten Bandung, 2006

Tabel 3.4

Segmentasi Pasar Wisatawan Mancanegara Di Kabupaten Bandung

\begin{tabular}{|c|c|}
\hline Aspek & Deskripsi \\
\hline $\begin{array}{l}\text { Aspek Geografis } \\
\text { (Geographic } \\
\text { Segmenting) }\end{array}$ & $\begin{array}{l}\text { Sebagian besar wisatawan berasal dari Eropa Barat, dan kini } \\
\text { mulai berkembang untuk wisatawan dari Malaysia dan } \\
\text { Singapura. }\end{array}$ \\
\hline $\begin{array}{l}\text { Aspek Demographic } \\
\text { (Demographic } \\
\text { Segmenting) }\end{array}$ & $\begin{array}{l}\text { Wisatawan usia remaja dan dewasa. } \\
\text { Memiliki edukasi yang baik. } \\
\text { Memiliki daya beli yang tinggi. }\end{array}$ \\
\hline $\begin{array}{l}\text { Aspek Psikologis } \\
\text { (Psychographic } \\
\text { Segmenting) }\end{array}$ & $\begin{array}{l}\text { Mayoritas bertujuan untuk rekreasi dan sebgian untuk } \\
\text { nostalgia. } \\
\text { Lama tinggal 1-2 hari. } \\
\text { Membutuhkan hotel berbintang. }\end{array}$ \\
\hline $\begin{array}{l}\text { Perilaku Berwisata } \\
\text { (Behaviouristic } \\
\text { Segmenting) }\end{array}$ & $\begin{array}{l}\text { Mayoritas menggunakan biro perjalanan wisata dan } \\
\text { mengikuti program kunjungan ke beberapa daerah seperti } \\
\text { Jawa dan Bali. } \\
\text { Apresiasi terhadap budaya Sunda dan keindahan alam tinggi. }\end{array}$ \\
\hline
\end{tabular}

Sumber: RIPPDA Kabupaten Bandung, 2006 
ARTIKEL

Gambaran Umum Pariwisata Kabupaten Bandung

Sebagai daerah yang tengah mengembangkan pariwisatanya, Kabupaten Bandung dapat diklasifikasikan sebagai destinasi pariwisata. Menurut Perda Kabupaten Bandung No. 6 Tahun 2006 tentang Rencana Induk Pengembangan Pariwisata Daerah (RIPPDA) Kabupaten Bandung Tahun 2006 Sampai Dengan Tahun 2016, objek dan daya tarik wisata di Kabupaten Bandung terdiri dari ODTW situ (danau), waduk/bendungan, curug, kawah, bumi perkemahan, perkebunan dan agro wisata. Berdasarkan uraian tersebut, terlihat bahwa Kabupaten Bandung memiliki potensi daya tarik wisata dan pajak daerah sektor pariwisata yang cukup baik.

Tingkat Kunjungan Wisata

Jumlah obyek wisata yang ada di Kabupaten Bandung sejak tahun 2010 sebanyak 53 obyek. Jumlah kunjungan yang sebanyak 4.607.330 orang pada tahun 2010. Berikut pemamran dalam tabel :

Tabel 3.5

Jumlah Kunjungan Wisata di Kabupaten Bandung Pada Tahun 2008-2010

\begin{tabular}{|l|l|l|l|l|}
\hline No. & Uraian & $\mathbf{2 0 0 8}$ & $\mathbf{2 0 0 9}$ & $\mathbf{2 0 1 0}$ \\
\hline 1. & Jumlah objek wisata (objek) & 49 & 49 & 53 \\
\hline 2. & Jumlah kunjungan wisata (orang) & 4.306 .602 & 5.458 .218 & 6.069 .539 \\
\hline 3. & Rata-rata kunjungan per objek wisata (orang) & 87.890 & 111.392 & 123.869 \\
\hline
\end{tabular}

Sumber: Dinas Pemuda, Olah raga dan Pariwisata Kabupaten Bandung 2011

Tabel 3.6

Jumlah Wisatawan di Kabupaten Bandung

\begin{tabular}{|c|c|c|c|}
\hline Tahun & Jumlah Wisatawan & Tahun & Jumlah Wisatawan \\
\hline 2007 & 3.340 .875 & 2010 & 6.069 .539 \\
\hline 2008 & 4.306 .602 & 2011 & 6.258 .843 \\
\hline 2009 & 5.458 .218 & 2012 & 6.645 .569 \\
\hline
\end{tabular}

Sumber: RPJMD Kab. Bandung Tahun 2010-1015

Destinasi Wisata

Berdasarkan data statistik Jawa Barat Dalam Angka 2010, tercatat bahwa Kabupaten merupakan peringkat ke-6 dalam potensi objek dan daya tarik wisata dengan jumlah lebih dari tiga puluh objek wisata. Beberapa yang menjadi andalan wisata Kabupaten Bandung adalah Kawah Putih, Terletak di wilayah selatan dengan jarak tempuh dari Kabupaten Bandung 46 KM menuju arah Ciwidey Kab. Bandung. Meski sudah ditemukan pada 1837, tapi kawasan ini baru menjadi objek wisata pada 
1987 setelah dikembangkan oleh PT Perhutani (Persero) Unit III Jabar dan Banten. Kemudian yang tak kalah menariknya adalah obyek wana wisata Bumi Perkemahan Ranca Upas memiliki area seluas 215 ha memiliki kekayaan alam perbukitan serta hutan alam yang sangat luas. Di atas ketinggian sekitar 1.700 dpl, hawa yang sangat sejuk di kisaran 18-23C menambah suasana alam di kawasan ini semakin memikat.

Karakteristik Wisatawan

Mengidentifikasi karakteristik wisatawan yang datang ke Kabupaten Bandung lebih dominan kepada para penikmat alam dan komunitas kreatif pengembangan ekowisata di Kawasan Wisata Kabupaten Bandung.

Pola Pergerakan Wisatawan

Tak berbeda dengan para pengunjung di Kabupaten Bandung, tempat wisata yang ada di Kabupaten Bandung banyak dikunjungi dari daerah-daerah di sekitar Jawa Barat. Tapi tidak sedikit pula wisatawan yang berasal dari Jawa Tengah dan Jawa Timur, dan bahkan dari luar Pulau Jawa ataupun mancanegara.

Potensi Wisata

Objek wisata di Kabupaten Bandung juga tidak kalah dengan yang ada di Kota Bandung. Objek wisata tersebut memiliki karakteristik dan potensi wisata khas daerah masing-masing, serta memiliki masyarakat yang telah memiliki kesadaran potensi wisata yang dimilikinya. Desa wisata di Kabupaten Bandung dimaksudkan untuk menjadi tujuan wisata alternatif di samping obyek wisata unggulan di kawasan Bandung selatan seperti Ciwidey dan Pangalengan serta Desa Laksana dan Ciburial

\section{Pola Pergerakan Penduduk}

Pergerakan di dalam Kabupaten Bandung didominasi oleh kalangan pekerja, pelajar, dan wirausahawan. Hal ini wajar mengingat Bandung sebagai ibu kota Jawa Barat dimana banyak sekali kantor pemerintahan yang berkedudukan di Kabupaten Bandung disamping banyak perusahaan yang mendirikan cabangnya di Kabupaten Bandung. Pada umumnya para pegawai negeri dan swasta itu bergerak dari tempat tinggalnya di sekitar Bandung seperti kopo, cibiru, sukajadi, antapani dan cimahi menuju arah pusat kota. Selain itu pergerakan di Kabupaten Bandung juga didominasi oleh para pelajar. Disamping pergerakan dalam kota, Kabupaten Bandung juga dikelilingi oleh kota-kota disekitarnya yang juga mempengaruhi kuantitas pergerakan yang ada di Bandung. Disebelah utara ada kota lembang yang terkenal dengan 
komoditas sayuran, yang sebagian besar disalurkan ke Kabupaten Bandung. Ada objek wisata Gunung Tangkuban Perahu yang merupakan salah satu tujuan utama pariwisata alam di bagian utara kota. Di selatan, kota Soreang yang merupakan ibu kota Kabupaten Bandung dan Perbukitan di kawasan Ciwidey merupakan penyebab utama adanya pergerakan dari dan ke Kabupaten Bandung. Disana terdapat perkebunan strawbery dan wisata alam yang tidak kalah populer dari Tangkuban Perahu, yaitu Kawah Putih dan Situ Patengan. Sementara itu di sebelah timur Bandung, adanya perubahan penggunaaan lahan meningkatkan aktivitas yang berakibat peningkatan jumlah pergerakan.

\section{Prasarana Sarana Transportasi}

Transportasi di Kabupaten Bandung terbagi menjadi sistem transportasi jalan raya, rel dan transportasi udara. Untuk pergerakan di Kabupaten Bandung, sistem pergerakan untuk masyarakat Kabupaten Bandung lebih mengarah pada kawasankawasan di pusat kota. Keberadaan jasa angkutan travel juga menjadi salah satu pendorong perkembangan kegiatan pariwisata di Kabupaten Bandung dimana banyak wisatawan yang datang ke Kabupaten Bandung dengan memanfaatkan jasa travel tersebut. Berbeda halnya di Kabupaten Bandung, lebih banyak menggunakan sistem transportasi jalan raya, seperti angkutan mum, bus, dan jasa transportasi tradisional seperti becak dan delman.

\section{Pembangunan Tol Seroja}

Soreang adalah ibukota Kabupaten Bandung, seiring dengan perkembangan otonomi daerah, peran kabupaten sebagai daerah otonomi sangat penting, sehingga dalam perkembangannya Soreang akan tumbuh menjadi pusat kegiatan dan seluruh aktivitas kehidupan. Pertumbuhan ini akan membawa dampak bertambahnya pergerakan dan perpindahan baik ke luar dan ke dalam daerah ini. Kabupaten Bandung dan Soreang disisi lain akan tumbuh dan berkembang secara signifikan. Kedua daerah ini akan mempunyai bangkitan dan tarikan satu sama lain yang cukup besar volumenya, sehinga diperlukan sistem jaringan jalan tol disamping ruas jalan Pasirkoja - Soreang yang saat ini mempunyai masalah dengan kapasitas yang sudah tidak memadai lagi. Dalam tinjauan sistem transportasi wilayah, diharapkan pembangunan jalan tol ini hendaknya ditinjau sebagai satu sistem terintegrasi yang sub-sistemnya saling mempengaruhi. 


\section{Perkembangan Wilayah Pintu Tol Soreang}

Jalan tol Soreang - Pasirkoja (SOROJA) merupakan jalan tol yangmenghubungkan antara Kabupaten Bandung dengan Soreang, melewati Desa Kopo, Gajah Mekar dan Cigondewah Kidul. Sistem transportasi Wilayah Kabupaten Bandung yang berfungsi sebagai daerah pendukung (hinterland), tidak dapat dipisahkan dari perkembangan sistem transportasi Kabupaten Bandung. Secara mum fungsi utama dari sistem transportasi adalah sebagai media interaksi antar daerah dalam sistem keterikatan ekonomi, komunikasi dan kegiatan lainnya, sehingga membentuk suatu jaringan pergerakan yang kontinyu.

\section{Tabel 3.7}

Luas Kawasan yang Potensial untuk Pengembangan Perkotaan di Sekitar Koridor Rencana

\begin{tabular}{|c|c|c|c|c|c|c|c|c|}
\hline No. & $\begin{array}{c}\text { Nama } \\
\text { Kecamatan }\end{array}$ & $\begin{array}{c}\text { Luas } \\
\mathbf{( H a )}\end{array}$ & $\begin{array}{c}\text { Lereng } \\
\mathbf{4 0 \%}\end{array}$ & $\begin{array}{c}\text { Rawan } \\
\text { Banjir }\end{array}$ & $\begin{array}{c}\text { Rawan } \\
\text { Erosi }\end{array}$ & Perairan & $\begin{array}{c}\text { Luas Kawasan } \\
\text { Pengembangan }\end{array}$ & $\mathbf{\%}$ \\
\hline 1 & Margahayu & $1.054,34$ & & 0 & & 23,89 & $1.030,46$ & $97,73 \%$ \\
\hline 2 & Margaasih & $1.796,53$ & & 0 & 139,93 & 19,72 & $1.636,88$ & $91,11 \%$ \\
\hline 3 & Ketapang & $2.116,24$ & 67,60 & 0 & & 14,56 & $2.034,08$ & $96,12 \%$ \\
\hline 4 & Soreang & $6.737,17$ & $3.591,45$ & 0 & 360,00 & 42,23 & $2.743,49$ & $40,72 \%$ \\
\hline
\end{tabular}

Sumber: Pra Studi Kelayakan Jalan Tol Pasirkoja - Soreang

\section{Pintu Tol Soreang sebagai Central Point Area}

Soreang merupakan salah satu titik sentral transportasi di Bandung Selatan. Terletak $18 \mathrm{~km}$ di sebelah selatan Kabupaten Bandung, daerah ini merupakan penghubung antara Kabupaten Bandung dan Ciwidey. Meski jarak dari Kabupaten Bandung cukup dekat, anda yang berkendara dengan menggunakan mobil butuh waktu lebih dari satu jam untuk mencapai Soreang. Hal ini dikarenakan kemacetan yang parah di sepanjang ruas jalan menuju Soreang, terutama di daerah Kopo Sayati dan Kawasan industri di Katapang. Kemacetan inilah yang menyebabkan Soreang kurang berkembang sebagai Kota Kabupaten. Pada zaman penjajahan Belanda, dibangun rel

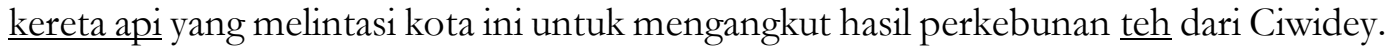
Jalur rel ini tersambung dengan jalur rel kereta api di Kabupaten Bandung. Namun, sekarang jalur ini sudah tidak dipakai lagi. 
ARTIKEL

Tabel 3.8

Volume Lalu Lintas yang Mewakili Jam Puncak Pagi, Puncak Sore dan Off-peak di Wilayah Studi

\begin{tabular}{|c|c|c|c|}
\hline No. & Tingkat Volume & $\begin{array}{c}\text { Periode } \\
\text { Waktu }\end{array}$ & $\begin{array}{c}\text { Total Volume Lalu Lintas } \\
\text { (smp/jam) }\end{array}$ \\
\hline 1 & Jam Puncak Pagi & $07: 30-08: 30$ & 5.157 .35 \\
\hline 2 & Off-Peak & $12: 30-13: 30$ & $2.803,13$ \\
\hline 3 & Jam Puncak Sore & $16: 30-17: 30$ & $5.718,72$ \\
\hline
\end{tabular}

Sumber: Pra Studi Kelayakan Jalan Tol Pasirkoja - Soreang

\section{Pembahasan}

Produk dan Lokasi BTA

Produk yang akan dianalisis dalam penelitian ini, yaitu: produk dari wisata kuliner, produk dari wisata belanja dan produk MICE. Aspek yang akan dianalisis melalui SWOT Internal dari produk wisata kuliner terdiri dari jenis dan ragam kuliner, kemudahan mendapatkan kuliner pilihan, harga, pelayanan, bentuk dan desain outlet dan aksesibilitas. Aspek yang akan dianalisis melalui SWOT Internal dari produk wisata belanja. Aspek yang akan dianalisis melalui SWOT Internal dari produk wisata MICE.

Analisis SWOT Internal Produk-Produk BTA

Matrik berikut akan menjelaskan Analisis SWOT Internal produk-produk BTA:

\begin{tabular}{|c|c|c|c|c|}
\hline No. & Komponen & Uraian & $\begin{array}{c}\text { Kekuatan } \\
(\mathrm{S})\end{array}$ & $\begin{array}{l}\text { Kelemahan } \\
\text { (W) }\end{array}$ \\
\hline \multirow[t]{8}{*}{1} & \multicolumn{4}{|l|}{ Wisata Kuliner } \\
\hline & Jenis dan ragam Kuliner & $\begin{array}{l}\text { Ragam kuliner baik tradisional maupun modern } \\
\text { lebih banyak }\end{array}$ & & * \\
\hline & $\begin{array}{l}\text { Kemudahan mendapatkan kuliner } \\
\text { pilihan }\end{array}$ & $\begin{array}{l}\text { Lokasi klaster mempermudah konsumen untuk } \\
\text { mendapatkan pilihannya dengan cepat dan } \\
\text { mudah }\end{array}$ & $*$ & \\
\hline & Harga produk kuliner & $\begin{array}{l}\text { Harga lebih murah karena biaya property, } \\
\text { karyawan dan pajak yang lebih murah }\end{array}$ & * & \\
\hline & Pelayanan terhadap wisatawan & Pelayanan terhadap kuliner & & * \\
\hline & Bentuk dan Desain Outlet & $\begin{array}{l}\text { Bentuk dan desain bangunan sesuai dengan } \\
\text { daerah asal kuliner }\end{array}$ & & $*$ \\
\hline & Aksesesibilitas & Kemudahan untuk mecapai BTA & * & \\
\hline & \multicolumn{2}{|l|}{ Sub Total 1} & 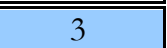 & 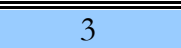 \\
\hline \multirow[t]{4}{*}{ 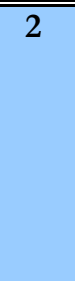 } & \multicolumn{4}{|l|}{ Wisata Belanja } \\
\hline & Jenis dan Ragam Produk & Ragam produk yang dapat dipilih lebih banyak & & * \\
\hline & $\begin{array}{l}\text { Kemudahan mendapatkan produk } \\
\text { pilihan }\end{array}$ & $\begin{array}{l}\text { Lokasi berupa kawasan mempermudah } \\
\text { konsumen untuk mendapatkan pilihannya } \\
\text { dengan cepat dan mudah }\end{array}$ & * & \\
\hline & Harga produk & $\begin{array}{l}\text { Harga lebih murah karena biaya property, } \\
\text { karyawan dan pajak yang lebih murah }\end{array}$ & * & \\
\hline
\end{tabular}


ARTIKEL

\begin{tabular}{|c|c|c|c|c|}
\hline \multirow[t]{5}{*}{ No. } & Komponen & Uraian & $\begin{array}{l}\text { Kekuatan } \\
\text { ( S ) }\end{array}$ & $\begin{array}{l}\text { Kelemahan } \\
\text { (W) }\end{array}$ \\
\hline & Pelayanan terhadap wisatawan & $\begin{array}{l}\text { Mengedepankan pelayanan tradisional } \\
\text { berdasarkan daerah asal kuliner }\end{array}$ & & $*$ \\
\hline & Bentuk dan Desain Outlet & $\begin{array}{l}\text { Bentuk dan desain bangunan sesuai dengan } \\
\text { daerah asal kuliner }\end{array}$ & & $*$ \\
\hline & Aksesesibilitas & $\begin{array}{l}\text { Kemudahan untuk mecapai lokasi wisata } \\
\text { belanja }\end{array}$ & $*$ & \\
\hline & \multicolumn{2}{|l|}{ Sub Total 2} & 3 & 3 \\
\hline \multirow[t]{12}{*}{ 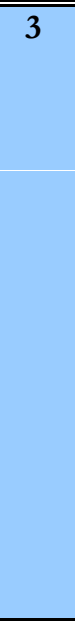 } & \multicolumn{4}{|l|}{ "Hotel dan MICE } \\
\hline & Jenis dan Ragam Hotel MICE & Jenis/Tingkat/katagori Hotel dan MICE & & $*$ \\
\hline & Jumlah Hotel dan MICE & Jumlah hotel dan MICE & & $*$ \\
\hline & Harga Hotel dan MICE & Harga/biaya hotel dan MICE & $*$ & \\
\hline & $\begin{array}{l}\text { Variasi/Pilihan Harga Hotel dan } \\
\text { MICE }\end{array}$ & Variasi/Pilihan Harga Hotel dan MICE & & $*$ \\
\hline & Kapasitas Hotel dan MICE & Kemampuan/daya tampung Hotel dan MICE & & $*$ \\
\hline & Pelayanan Hotel dan MICE & Kualitas Pelayanan Hotel dan MICE & & $*$ \\
\hline & Bentuk dan desain Hotel dan MICE & Bentuk dan desain bangunan Hotel dan MICE & & $*$ \\
\hline & $\begin{array}{l}\text { Kemudahan mendapatkan Hotel dan } \\
\text { MICE }\end{array}$ & Kemudahan untuk reserve Hotel dan MICE & $*$ & \\
\hline & $\begin{array}{l}\text { Kredibilitas penyelenggaran kegiatan } \\
\text { MICE }\end{array}$ & $\begin{array}{l}\text { Kepercayaan masyarakat terhadap pengalaman } \\
\text { dalam penyelenggaraan MICE }\end{array}$ & & $*$ \\
\hline & Aksesbilitas terhadap Hotel dan MICE & Kemudahan pencapaian lokasi & $*$ & \\
\hline & Sub Total 3 & & 3 & 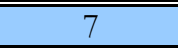 \\
\hline \multirow[t]{11}{*}{4} & Kawasan BTA & & & \\
\hline & Kelayakan Ekonomis BTA & & ** & \\
\hline & Konsep One Stop Travelling & & $*$ & \\
\hline & Nilai Investasi & & & * \\
\hline & $\begin{array}{l}\text { Terdapat Desitinasi Wisata Yang } \\
\text { Berbeda }\end{array}$ & & $*$ & \\
\hline & $\begin{array}{l}\text { Kenyamanan (Bebas Banjir, Bebas } \\
\text { Macet) }\end{array}$ & & $*$ & \\
\hline & Konsep Menyatu Dengan Alam & & $*$ & \\
\hline & Transit Menuju Destinasi Wisata Lain & & * & \\
\hline & Persaingan Dengan Kawasan Lain & & & * \\
\hline & Publikasi & & & $*$ \\
\hline & Sarana Prasarana Lingkungan & & & $*$ \\
\hline \multicolumn{3}{|c|}{ Jumlah Sub 4} & 6 & 4 \\
\hline \multicolumn{3}{|c|}{ Jumlah } & 15 & 17 \\
\hline
\end{tabular}

Analisis SWOT Eksternall Produk-Produk BTA:

Produk yang akan dianalisis dalam penelitian ini, yaitu: aspek wisatawan, kondisi destinasi wisata, dukungan pemerintah, dan produk/destinasi wisata. Aspek yang akan dianalisis melalui SWOT eksternall dari komponen wisatawan terdiri dari: Jumlah wisatawan ke Kabupaten Bandung, Daya Tampung wisata Kabupaten Bandung, Daya Beli wisatawan, tujuan wisata dan Waktu Kunjungan/tinggal. Aspek yang akan dianalisis melalui SWOT eksternall dari komponen destinasi wisata terdiri 
ARTIKEL

dari: Waktu pencapaian satu destinasi, Waktu pencapaian destinasi secara keseluruhan, Kenyamanan dan Biaya. Aspek yang akan dianalisis melalui SWOT eksternall dari komponen dukungan pemerintah, terdiri dari: kebjakan dan nilai investasi. Aspek yang akan dianalisis melalui SWOT eksternall dari komponenproduk destinasi wisata, terdiri dari: Jenis dan Ragam produk, enis dan Ragam Destinasi Wisata dan harga. Untuk memahami SWOT Eksternall dapat melalui matrik berikut :

MATRIK SWOT EKSTERNALL

\begin{tabular}{|c|c|c|c|c|}
\hline No. & Komponen & Uraian & $\begin{array}{c}\text { Peluang } \\
(\mathrm{O})\end{array}$ & $\begin{array}{c}\text { Ancaman } \\
(\mathrm{T})\end{array}$ \\
\hline \multirow[t]{6}{*}{1} & \multicolumn{4}{|c|}{ Karakterisitik Wisatawan } \\
\hline & $\begin{array}{l}\text { Jumlah wisatawan ke } \\
\text { Kabupaten Bandung }\end{array}$ & $\begin{array}{l}\text { Jumlah wisatawan ke Kabupaten } \\
\text { Bandung terus meningkat }\end{array}$ & $*$ & \\
\hline & $\begin{array}{l}\text { Daya Tampung Wisata } \\
\text { Kabupaten Bandung }\end{array}$ & $\begin{array}{l}\text { Daya tampung Kabupaten Bandung } \\
\text { terbatas terhadap wisatawan }\end{array}$ & $*$ & \\
\hline & Daya Beli wisatawan & $\begin{array}{l}\text { Kemampuan konsumsi terhadap } \\
\text { destinasi wisata }\end{array}$ & $*$ & \\
\hline & $\begin{array}{l}\text { Waktu } \\
\text { Kunjungan/tinggal }\end{array}$ & Lama bekunjung/tinggal wisatawan & & $*$ \\
\hline & \multicolumn{2}{|l|}{ Sub Total 1} & 3 & 1 \\
\hline \multirow[t]{6}{*}{4} & \multicolumn{2}{|l|}{ Peranan Pemerintah } & & \\
\hline & \multirow{3}{*}{ Kebijakan } & Kebijakan Pemerintah Daerah & $*$ & \\
\hline & & Konsistensi kebijakan & & * \\
\hline & & Dukungan pembiayaan dari APBD & * & \\
\hline & Pajak & & $*$ & \\
\hline & Sub Total 4 & & 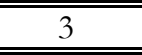 & $\overline{1}$ \\
\hline \multirow[t]{6}{*}{5} & Pembangunan BTA & & & \\
\hline & Ketertarikan Investor & & * & \\
\hline & Ketersediaan Lahan & & & $\bar{*}$ \\
\hline & $\begin{array}{l}\text { Ketersediaan Prasarana } \\
\text { Sarana Wilayah } \\
\end{array}$ & & & * \\
\hline & Moda Transportasi & & & $*$ \\
\hline & \multicolumn{2}{|l|}{ Sun Total 5} & 1 & 3 \\
\hline \multicolumn{3}{|r|}{ Jumlah } & 7 & (5 \\
\hline
\end{tabular}

\section{Pilihan Strategi Berdasarkan Analisis SWOT}

Faktor-Faktor Kunci Strategis baik eksternall maupun internal masing-masing ditetapkan sebanyak lima faktor kunci seperti terlihat pada Tabulasi Matriks SWOT di bawah ini:

\section{Lima Peluang ( O )}

- Jumlah wisatawan yang terus meningkat

- Daya beli wisatawan yang tinggi

- Dukungan dari pemerintah

- Pengurangan/Pemotongan pajak (tax holiday) 
- Ketertarikan investor

\section{Lima Ancaman ( $T$ )}

- Waktu kunjung wisatawan yang singkat

- Konsistensi kebijakan pemerintah

- Ketersediaan lahan

- Ketersediaan prasarana sarana wilayah

- Ketersediaan moda transportasi

\section{Lima Kekuatan ( S )}

- Kemudahan mendapatkan destinasi/produk wisata

- Harga dan biaya wisata yang relatif rendah

- Kenyamanan dan efektifitas berwisata

- Transit ke destinasi wisata lain yang ada di wilayah Kabupaten Bandung

- Aksesibilitas menuju kawasan BTA

\section{Lima Kelemahan ( W )}

- Jenis dan ragam destinasi/produk wisata

- Jumlah dan kualitas desitinasi/produk wisata

- Kualitas layanan kepada wisatawan

- Bentuk/fasade dan desain fisik destinasi wisata

- Ketersediaan prasarana sarana kawasan BTA

Dari hasil analisis didapatkan matriks SWOT yang memplot dan mematrikskan faktor lingkungan eksternall dan faktor lingkungan internal untuk memperoleh strategi yang dibutuhkan, tepat dan handal bagi pengembangan kawasan BTA dalam mengantisipasi semua alternatif kemungkinan, sekaligus hubungan sebab akibat antar dimensi tersebut sehinga tercipta kawasan BTA yang layak untuk dibangun.

\section{MATRIK SWOT}

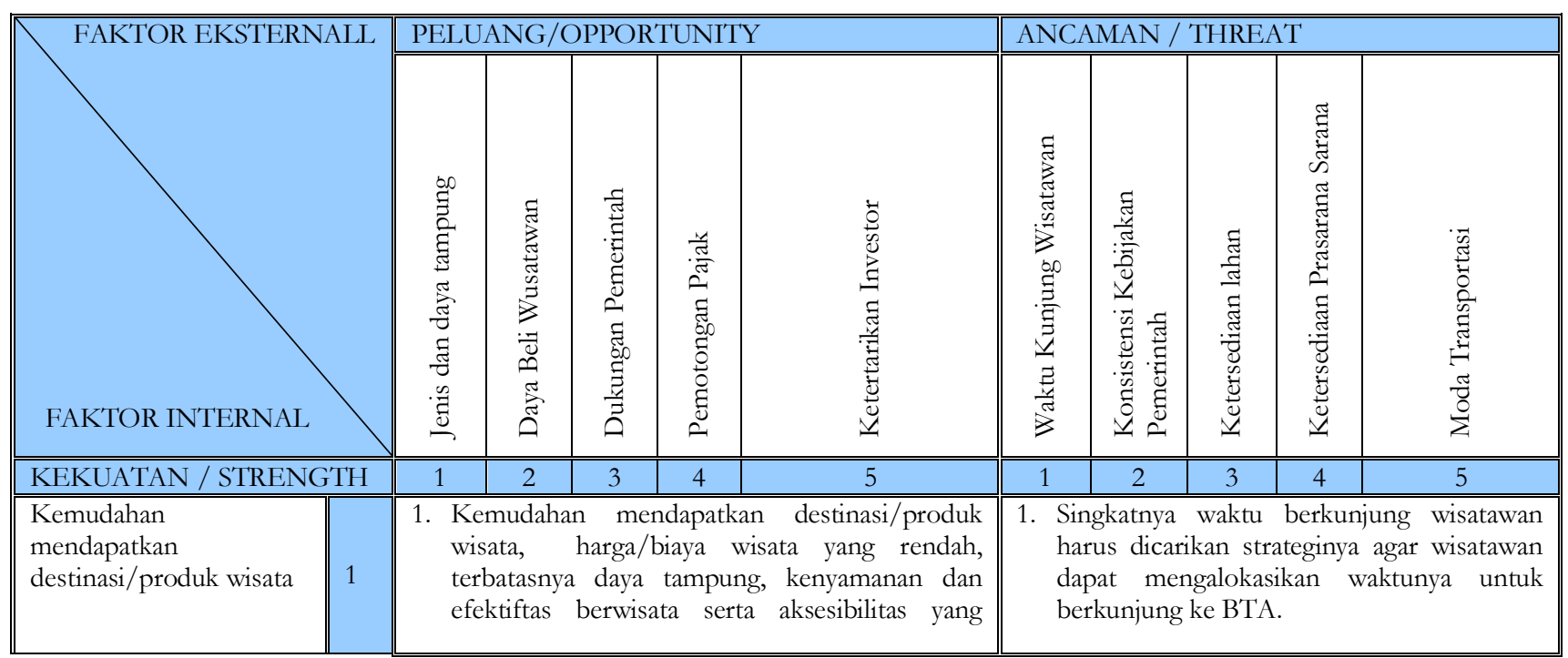




\begin{tabular}{|c|c|c|c|}
\hline $\begin{array}{l}\text { Harga dan biaya wisata } \\
\text { yang relatif rendah }\end{array}$ & 2 & \multirow{4}{*}{$\begin{array}{l}\text { mudah harus dapat menarik/menampung } \\
\text { wisatawan yang datang ke Kabupaten Bandung. } \\
\text { 2. BTA sebagai chanelling kepada destinasi wisata } \\
\text { di wilayah Kabupaten Bandung merupakan } \\
\text { keunggulan dibanding destinasi lain yang ada di } \\
\text { Kabupaten Bandung. Untuk itu BTA harus } \\
\text { dapat menjalankan fungsinya dengan baik. } \\
\text { 3. Dukungan pemerintah merupakan hal yang } \\
\text { penting untuk mendukung keberadaan BTA. } \\
\text { Dukungan pemerintah daerah bukan hanya pada } \\
\text { saat pembangunan, tapi juga pada saat } \\
\text { operasional BTA. termasuk kebijadkan dalam hal } \\
\text { perpajakan. }\end{array}$} & \multirow{4}{*}{$\begin{array}{l}\text { 2. Konsistensi kebijakan perlu dibuatkan } \\
\text { peraturannya. Hal ini agar jaminan hukum } \\
\text { sebagai perlindungan bagi investor lebih } \\
\text { pasti. Peraturan tersebut dapat berupa Perda } \\
\text { atau Perbup } \\
\text { 3. Dukungan prasarana sarana dan pengadaan } \\
\text { moda transportasi dari pemerintah sangat } \\
\text { diperlukan. Oleh karena itu perlu dibuat } \\
\text { kebijakan yang berbentuk peraturan. } \\
\text { 4. Dukungan pemerintah dalam pengadaan } \\
\text { lahan bagi kawasan BTA sangat diperlukan. } \\
\text { Untuk itu perlu kiranya pemerintah } \\
\text { membentuk gugus tugas pelaksana } \\
\text { pembangunan kawasan BTA. }\end{array}$} \\
\hline $\begin{array}{l}\text { Kenyamanan dan } \\
\text { efektifitas berwisata }\end{array}$ & 3 & & \\
\hline $\begin{array}{lrr}\text { Transit } & \text { ke } & \text { destinasi } \\
\text { wisata lain } & \text { yang ada di } \\
\text { wilayah } & \text { Kabupaten } \\
\text { Bandung } & \end{array}$ & 4 & & \\
\hline $\begin{array}{ll}\text { Aksesibilitas } & \text { menuju } \\
\text { kawasan BTA } & \\
\end{array}$ & 5 & & \\
\hline $\begin{array}{l}\text { KELEMAHAN } \\
\text { WEAKNESS }\end{array}$ & I & $\begin{array}{l}\text { 1. Jenis/ragam dan jumlah destinasi/produk wisata } \\
\text { harus dibatasi/ditentukan sesuai dengan } \\
\text { karakteristik dan daya tampung kawasan BTA. } \\
\text { Sementara untuk menjaga kualitas } \\
\text { destinasi/pelayanan wisata perlu dilakukan } \\
\text { standarisasi terhadap } \\
\text { destinasi/pelayanan outlet. } \\
\text { 2. Desain fisik outlet/destinasi wisata tidak perlu } \\
\text { meniru outlet/destinasi wisata yang ada di } \\
\text { Kabupaten Bandung. Desain outlet/destinasi } \\
\text { wisata BTA dirancang dengan cirri khas sendiri. } \\
\text { 3. Konsep/rancangan kawasan BTA, keberadaan } \\
\text { prasarana sarana, dukungan pemerintah dan } \\
\text { aspek perpajakan ditujukan agar investor tertarik } \\
\text { untuk berinvestasi di BTA. }\end{array}$ & $\begin{array}{l}\text { 1. Jenis, ragam, kualitas layanan, desain } \\
\text { outlet/produk, prasarana sarana, } \\
\text { keteresdiaan moda transportasi dirancang } \\
\text { agar dapat menarik/meningkatkan waktu } \\
\text { kunjungan wisatawan. } \\
\text { 2. Jaminan ketersediaan lahan dan dukungan } \\
\text { pemerintah daerah harus mendapat } \\
\text { kepastian hukum. Hal ini dilakukan untuk } \\
\text { perlindungan investasi yang dilakukan oleh } \\
\text { investor. } \\
\text { 3. Publikasi merupakan bagian penting untuk } \\
\text { pengenalan kepada masyarakat, khususnya } \\
\text { mereka yang tinggal di Jakarta dan } \\
\text { sekitarnya. Hal penting lainnya dalam } \\
\text { publikasi adalah konten dan media yang } \\
\text { dipergunakan dalam publikasi. Pemilihan } \\
\text { media untuk publikasi akan menentukan } \\
\text { efektifitas publikasi itu sendiri. }\end{array}$ \\
\hline
\end{tabular}

\section{Simpulan}

Berdasarkan analisis SWOT terhadap faktor internal dan internal, posisi pembangunan kawasan BTA berada pada kuadran II/layak dikembangkan. Dimana dari analisis kompenen BTA menunjukan faktor eksternall bernilai posisitf, sementara analisis faktor internal menunjukan nilai yang negatif. Jadi dengan demikian berdasarkan analisis SWOT faktor eksternall dan internal pembangunan kawasan BTA berada pada kuadran II. Kuadran II dapat diartikan bahwa pembangunan kawasan BTA layak untuk dikembangkan.

\section{Saran}

Untuk mendukung keberhasilan pembangunan kawasan BTA berdasarkan analisis SWOT factor eksternal dan internal maka disarankan untuk melakukan hal-hal 
sebagai berikut: (1) Penyusunan studi kelayakan pembangunan kawasan BTA. Hal ini perlu dilakukan agar tergambar dengan jelas kelayakan pembangunan kawasan BTA baik dari aspek ekonomis, social, dan aspek-aspek yang lainnya. Lebih dari itu studi kelayakan ini akan menjadi panduan bagi calon investor untuk berpartisipasi dalam pembangunan kawasan BTA.(2) penyusunan/rancangan konsep kawasan BTA secara menyeluruh dan terintergrasi yang meliputi; daya tampung, standarisasi pelayanan, kebutuhan prasarana sarana kawasan dan wilayah, rancang bangun fisik kawasan, dll. Penentuan daya tampung wisatawan yang berkunjung ke BTA. Hal ini dilakukan agar kenyamana wisatawan dalam melakukan aktifitas wisatanya dapat terjaga dengan baik. Penambahan daya tampung wisatawan dilakukan secara bertahap disesuaikan dengan tren kunjungan wisatawan, minat investor dan dukungan prasarana sarana oleh pemerintah. Diamping itu perlu dilakukan penentuan/pembatasan jenis dan ragam produk/destinasi wisata yang akan dibangun di BTA. Hal ini ditujukan agar positioning BTA terhadap destinasi/produk wisata yang berada di Kabupaten Bandung menjadi jelas. Berdasarkan jenis dan ragam produk/destinasi wisata yang berada di BTA akan terlihat apakah BTA merupakan komplemen, subtitusi, atau competitor bagi produk/destinasi wisata yang berada di Kabupaten Bandung.

Desain outlet/destinasi wisata BTA dirancang dengan ciri khas sendiri. Hal ini dilakukan agar tampilan outlet/destinasi wisata BTA menjadi pembeda dengan outlet/destinasi wisata BTA yang berada di Kabupaten Bandung.(3) meminta dukungan dari pemerintah dalam pembangunan BTA. Bentuk dukungan yang diperlukan dari pemerintah diantaranya, adalah: pembentukan gugus tugas, penyediaan prasarana sarana kawasan BTA, pembiayaan untuk penyusunan kelayakan BTA, penyediaan lahan, keringan pajak, penyediaan moda transportasi, penyusunan studi kelayakan dan upaya untuk menarik investor. Kemudian yang tidak kalah pentingnya adalah terbitnya paying hukum keberadaan BTA. Sehingga ada kepastian hukum bagi pengelola, investor dan wisatawan. (4) melakukan publikasi yang tepat sasaran. Publikasi ditujukan kepada investor maupun masyarakat yang memiliki potensi berwisata ke BTA, terutama kepada penduduk yang tinggal di Jakarta dan sekitarnya. Hal penting lainnya yaitu; media yang dipergunakan dalam publikasi. Pemilihan media untuk publikasi akan menentukan efektifitas publikasi itu sendiri. 
ARTIKEL

\section{DAFTAR PUSTAKA}

Allison M, Kaye Jude. 2005. Perencanaan Strategis Bagi Organisasi Nirlaba, Jakarta : Yayasan Obor Indonesia.

Atmosudirdjo, Prajudi. 1990. Dasar-dasar Administrasi Negara. Jakarta : Ghalia Indonesia.

------1990. Teori Organisasi, Jakarta : STIA LAN Press.

Bhatia, A.K. 2002. Tourism Development : Principles and Practices. New Dehli; Sterling Publishers Private Limited.

Bratakusumah, R.D.S, 2003. Perencanaan Pembangunan Daerah, Strategi Menggali Potensi Dalam Mewujudkan Otonomi Daerah.Jakarta : Gramedia, Pustaka Utama.

Bryson, J.M. 1995. Strategic Planning for Public and Nonprofit Organizations: A Guide to Strengthening and Sustaining Organizational Achievement, San Francisco : Jossey-Bass.

David, F.R. 2009. Strategic Management : Concepts and Cases. New Jersey: Pearson Educational International Inc.

Dess, Gregory and Miller, Alex. 1993. Strategic Management, Singapore : McGraw Hill.

Dess, Lukpkin Einer. 2008. Strategic Management Tex and Cases Fourt Edition, China: McGraw Hill International Edition.

Drucker, Peter.1997. Managing ini A Time of Great Change, Terjemahan oleh Agus Teguh Handoyo, "Manajemen di Tengah Perubahan Besar", Jakarta: Elex Media Komputindo.

Dwiyanto, Agus. 2012. Reformasi Birokrasi Publik di Indonesia, Jakarta : GMUP.

Edward III. George C. 1980. Implementing Public Policy. Washington DC : Congressional Quarterly Press.

Dess, Lukpkin Einer. 2008. Strategic Management Tex and Cases Fourt Edition, China : McGraw Hill International Edition.

Drucker, Peter.1997. Managing ini A Time of Great Change, Terjemahan oleh Agus Teguh Handoyo, "Manajemen di Tengah Perubahan Besar", Jakarta: Elex Media Komputindo.

Dwiyanto, Agus. 2012. Reformasi Birokrasi Publik di Indonesia, Jakarta : GMUP.

Edward III. George C. 1980. Implementing Public Policy. Washington DC : Congressional Quarterly Press.

Goelner, C.R and Ritchie, J.R.B. 2009. Tourism : Principle, Practices, Philosophies. New Jersey: John Wiley \& Sons, Inc.

Goodstein, Leonard; Nolan, Timothy; Pfeiffer, J. William. 1993. Applied Strategic Planning; How to Develop A Plan That Really Works.USA : McGraw-Hill Inc.

Goodstein, Nolan and Pfeiffer. 1993. Applied Strategic Planning; How to Develop apian That Really Works.USA : McGraw-Hill Inc.

Gunn, Claire A. 1994. Tourism Planning. 2nd ed. New York : Taylor \& Francis.

Hasswell, Harold. 1990. The Structure and Function of Community in Society. New York: New Haven Press.

Healy, Patsy, 1997. Collaborative Planning, Shaping Places In Fragmented Societies. Planning Environment Cities.

, 2000. Planning Theory and Urban and Regional Dynamics : A Comment on Yittachel and Huxley. International Journal of Hoban and Regional Research. 24(4). 
Hicks, Herbert G., Gullet, Ray C. 1975. Organization: Theory and Behavior. Tokyo : McGraw Hill International Book Company.

Holt, David H. 1993. Management. New Jersey : Prentice Hall.

Hunger, David J. 1996. Strategic Management. USA : Addison-Wesley.

Hunger, David J. dan T.L. Wheelen,2000. Strategic Management. New Jersey :AddisonWesley.

Ibrahim, Amin. 2009. Pokok-Pokok Administrasi Publik dan Implementasinya, Jakarta : Refika Aditama.

Kotler, Philip; Ferrell, O.C.; dan Lamb, Charles. 1987. Strategic Marketing for Nonprofit Organiation. Englewood Cliffs: Prentice Hall.

Kotler, Philip; Kohn Bowen \& James Makens. 2003. Marketing for Hospitality \& Tourism. Englewood Cliffs: Prentice Hall .

Koeswara, E. 2001. Otonomi Daerah Untuk Demokrasi dan Kemandirian Rakyat. Jakarta : Yayasan Pariba

Kearns, Kevin P. 1992. From Comparative Advantage to Damage Control: Clarifying Strategic Issues using SWOT Analysis, "Non Profit Management and Leadership. USA : Prentice Hall.

Lembaga Administrasi Negara RI. 2003. Sistem Administrasi Negara Kesatuan Republik Indonesia. Buku I : Prinsip-prinsip Penyelenggaraan Negara, Jakarta: LAN RI

Lickorish, Leonard dan Jefferson, Allan. 1989. Marketing Tourism : A Practical Guide, UK : Longman.

Marpaung, Happy dan Bahar, Herman, 2000. Pengantar Pariwisata, Bandung: Alfabeta.

McIntosh, Robert W., dan Charles R. Goeldner, 1995. Tourism Principles, Practices, Pbilosophies. USA : Grid Publishing Inc.

Mercer, James L. 1991. Strategic Planning for Public Managers. New York: Quorum Books.

Middleton, Victor T.C. 1988. Marketing in Travel and Tourism. Oxford: Heinemann Professional Publishing Ltd.

Murphy. Peter, E. 1985. Tourism A Community Approach, New York : Routledge.

Nieboer, N. 2010. "Strategic Planning Process Model: A Step Further", Emerald Group Publishing Limited, <www.emeraldinsight.com/reprints>. Netherlands: Delft University of Technology. (07/01/2014)

Parson, Wayne. 2008. Public Policy. Pengantar Teori dan Paktik Analisis Kebijakan. UK: Queen Mary University of London.

Pfiffner, John M. 1935. Public Administration. New York : The Ronald Press Company.

Picard, Michel. 2006. Pariwisata Budaya dan Budaya Pariwisata. Penyunting Ade Prasetie Wahyo, Penerjemah : Jean Coutau dan Warih Wisatsana, Jakarta: Kepustakaan Populer Gramedia dan Ecole Francaise d'Extreme-Orient.

Rangkuti, Freddy.2015. Analisis SWOT: Teknik Membedah Kasus Bisnis. Jakarta:Gramedia Pustaka Utama,

Robbins, Stephen dan Mary Coulter. 1997. Organization Behaviour. International Edition, Singapore : McGraww-Hill Inc.

Rosenberg, Jerry M. 1995. Dictionary of Marketing and Advertising. Toronto : John Wiley \& Sons, Inc..

Salusu. 2005. Pengambilan Keputusan Stratejik ; Untuk Organisasi Publik dan Organisasi Non Profit. Jakarta: Grasindo.

Santosa, Pandji. 2009. Administrasi Publike, Teori dan Aplikasi Good Governance, Jakarta: Refika Aditama. 
ARTIKEL

Sasmiyarsi K. Sasmoyo. 1997. Perencanaan Pariwisata Berkelanjutan. Jakarta : Gramedia.

Siagian, Sondang P. 1995. Manajemen Stratejike. Jakarta : Bumi Aksara.

Simerson, K. 2011. Strategic Planning : A Practical Guide to Strategy Formulation and Excecution, California: ABC-CLIO, LLC.

Singarimbun, Masri dan Sofyan Effendi. 1999. Metode Penelitian Survei. Jakarta : LP3ES.

Soekadijo, R.G. 1996. Anatomi Pariwisata. Jakarta : Bumi Aksara.

Sondakh, A. 2010. Jendela Pariwisata Angelina Sondakh, Perkembangan Pariwisata Indonesia 1-3. Jakarta: Kesaint Blank.

Spillane, James, 1987. Pariwisata Indonesia; Sejarah dan Prospeknya, Yogjakarta: Kanisius.

Steiner. George, 1997. Strategic Planning, What Every Manager Must Know, New York, London, Toronto, Sydney, Singapore: Free Press.

Steiner, George dan John F. Steiner. 2000. Bossiness, Government, and Society-A Managerial Perspective, Ninth Edition. USA: McGraw-Hill Inc.

Stoner, James AF. Dan Wankel, Charles. 1986. Management. New Delhi : Prentice Hall of India.

Taylor, James W. 1985. Strategic Planning for Successful Business. New York : Modern Business Report.

Thomson. Arthur A. Jr., dan Strivkland III, A.J. 1980. Strategic Formulation and Implementation. Plano, Texas : Business Publication, Inc.

Winardi. 1989. Pengantar Tentang Teori Sistem and Analisis Sistem. Bandung: Mandar Maju.

Winardi. 1994. Manajemen Konflik (Konflik Perubahan \& Pengembangan) Bandung: Mandar Maju.

Yoeti, Oka, A, 2000. Ecotourism : Pariwisata Berwawasan Lingkungan. Jakarta: Pertja.

-----------, 2001. Ilmu Pariwisata, Sejarah, Perkembangan dan Prospeknya. Jakarta: Pertja

\section{Dokumen :}

Undang-Undang Nomor 25 Tahun 2004 tentang Perencanaan Stratejik Nasional

Undang-Undang RI Nomor 10 tahun 2009 tentang Kepariwisataan

Badan Pusat Statistik Kabupaten Bandung, Kabupaten Bandung Dalam Angka.

Dinas Kebudayaan dan Pariwisata Kabupaten Bandung, 2011. Data Kepariwisataan

Kabupaten Bandung.

Pemerintah Kabupaten Bandung 2014. Rencana Pembangunan Jangka Panjang Daerah (RPJPD) Kabupaten Bandung Tabun 2013-2018.

Lembaga Administrasi Negara, RI, 2000, Modul2 Sosialisasi AKIP, BPKP-LAN, Jakarta. Program Pascasarjana Fakultas Ilmu Sosial dan Politik Universitas Padjadjaran, 2009. Panduan Penyusunan dan Penulisan Tesis dan Disertasi. Bandung. Fisip Unpad

Antariksa, Basuki, 2012 : Peluang dan Tantangan Pengembangan Pariwisata di Indo

\section{Jurnal}

Antariksa, Basuki, 2012 : Peluang dan Tantangan Pengembangan Pariwisata di Indonesiawww.budpar.go.id/asp/detil.asp. (02/17/2014)

Nirwandar, Sapta DR, 2007 : Pembangunan Sektor Pariwisata di Era Otonomi Daerah.

Sari, A. L. (2017). THE ROLE OF SOCIAL WORKERS IN THE DEVELOPMENT OF TOURISM VILLAGES. JISPO: Jurnal IImu Sosial dan IImu Politik, 7(2), 1-23.

Dulkiah, M. (2017). The Impact of Cash Transfer on Family's attitude and Copying Mecanism. JISPO: Jurnal IImu Sosial dan IImu Politik, 7(1), 102-112.

Ishak, D., Maolani, D. Y., \& Engkus, E. (2017). KONSEP KINERJA DALAM STUDI ORGANISASI PUBLIK. JISPO: Jurnal IImu Sosial dan IImu Politik, 7(2), 101-120. 
Ishak, D., Maolani, D. Y., \& Engkus, E. (2017). KONSEP KINERJA DALAM STUDI ORGANISASI PUBLIK. JISPO: Jurnal IImu Sosial dan IImu Politik, 7(2), 101-120. Irwandi, I., \& Chotim, E. R. (2017). ANALISIS KONFLIK ANTARA MASYARAKAT, PEMERINTAH DAN SWASTA. JISPO: Jurnal IImu Sosial dan IImu Politik, 7(2), 24-42.

\section{Media Masa}

Sunaryo Wirastuti, Media Indonesia, 1 Desember 2007

Sinar Harapan, Bidik Wisatawan Lewat ITCEF 2013, www-shnews.co/detile-24154bidik- wisatawan-lewat-itcef-2013-html. (02/17/2014) 